\title{
Identification and Modeling Carbon and Energy Fluxes from Eddy Covariance Time Series Measurements in Rice and Rainfed Crops ${ }^{\dagger}$
}

\author{
Víctor Cicuéndez ${ }^{1, *}{ }^{\oplus}$, Javier Litago ${ }^{1}$, Víctor Sánchez-Girón ${ }^{2}$, Laura Recuero ${ }^{3}$, César Sáenz ${ }^{1}[$ and \\ Alicia Palacios-Orueta ${ }^{2,3}$
}

1 Departamento de Economía Agraria, Estadística y Gestión de Empresas, ETSIAAB, Universidad Politécnica de Madrid (UPM), Avda. Complutense 3, 28040 Madrid, Spain; javier.litago@upm.es (J.L.); cesar.saenzf@alumnos.upm.es (C.S.)

2 Departamento de Ingeniería Agroforestal, ETSIAAB, Universidad Politécnica de Madrid (UPM), Avda. Complutense 3, 28040 Madrid, Spain; victor.sanchezgiron@upm.es (V.S.-G.); alicia.palacios@upm.es (A.P.-O.)

3 Centro de Estudios e Investigación Para la Gestión de Riesgos Agrarios y Medioambientales (CEIGRAM), Universidad Politécnica de Madrid (UPM), C/Senda del Rey 13 Campus Sur de prácticas de la ETSIAAB, 28040 Madrid, Spain; laura.recuero@upm.es

* Correspondence: victor.cicuendez.lopezocana@alumnos.upm.es

+ Presented at the 13th EFITA International Conference, online, 25-26 May 2021.

Citation: Cicuéndez, V.; Litago, J.; Sánchez-Girón, V.; Recuero, L.; Sáenz, C.; Palacios-Orueta, A. Identification and Modeling Carbon and Energy Fluxes from Eddy Covariance Time Series Measurements in Rice and Rainfed Crops. Eng. Proc. 2021, 9, 9. https://doi.org/10.3390/

engproc2021009009

Academic Editors: Dimitrios Aidonis and Aristotelis Christos Tagarakis

Published: 19 November 2021

Publisher's Note: MDPI stays neutral with regard to jurisdictional claims in published maps and institutional affiliations.

Copyright: () 2021 by the authors. Licensee MDPI, Basel, Switzerland. This article is an open access article distributed under the terms and conditions of the Creative Commons Attribution (CC BY) license (https:// creativecommons.org/licenses/by/ $4.0 /)$.
Abstract: Gross primary production (GPP) represents the carbon (C) uptake of ecosystems through photosynthesis and it is the largest flux of the global carbon balance. Our overall objective in this research is to identify and model GPP dynamics and its relationship with meteorological variables and energy fluxes based on time series analysis of eddy covariance (EC) data in two different agroecosystems, a Mediterranean rice crop in Spain and a rainfed cropland in Germany. Crops exerted an important influence on the energy and water fluxes dynamics existing a clear feedback between GPP, meteorological variables and energy fluxes in both type of crops.

Keywords: gross primary production (GPP); energy fluxes; time series analysis; feedback; Grangercausality tests

\section{Introduction}

The understanding of the $\mathrm{CO}_{2}$ flux between the biosphere and atmosphere is essential for assessing the carbon cycle and its influence on global climate change. Gross primary production (GPP) represents the $\mathrm{C}$ uptake of ecosystems through photosynthesis and it is the largest flux of the global carbon balance. Crop GPP contributes approximately $15 \%$ of global carbon dioxide fixation [1].

Climate determines carbon, water and energy fluxes on a seasonal to interannual time scale creating a complex pattern of $\mathrm{CO}_{2}$ exchange between the atmosphere and the ecosystem. Meanwhile, the ecosystem itself is responsible for strong feedback processes to climate [2]. Jung et al. [3] showed the strong connections between GPP and energy fluxes at a global scale; however, the relationships between fluxes should be studied at a local scale in different ecosystems.

The eddy covariance (EC) technique has been established as a valid method to measure meteorological variables as well as carbon, water and energy fluxes between ecosystems and the atmosphere [4]. The high temporal resolution of EC measurements makes the statistical time series analysis (TSA) an excellent method to analyze and study these data. TSA in the time and frequency domains provides tools and methodologies to model and forecast these variables and their relationship based on their dynamics [5]. Carbon, energy and water fluxes could be analyzed by TSA and be used as an excellent indicator of the 
phenology of ecosystems monitoring several characteristics of the ecosystems such as, cycles, evolution and trends.

Our overall objective in this research was to identify and model the GPP dynamics and its relationship with meteorological variables and energy fluxes based on time series analysis of EC data in two different agroecosystems, a Mediterranean rice crop in Spain and a rainfed cropland in Germany.

\section{Material and Methods}

\subsection{Study Site}

Two EC flux towers integrated into the FLUXNET micrometeorological tower sites [6] have been selected for this research.

The first one is situated in Gebesee (Germany) in an experimental agricultural area which has been cultivated since 1970 mainly with cereals, potato and sugar beet. More details on the site can be found in Anthoni et al. [7]. The study period analyzed of this flux tower is from 1 January 2001 to 31 December 2014 in which has been cultivated rainfed crops such as wheat, barley and potato. The area is characterized by a temperate climate $(\mathrm{Cfb})$ according to Köppen-Geiger classification.

The second one is placed in El Saler-Sueca in Valencia (Spain) in a rice crop [8]. The area is characterized by a Mediterranean climate (Csa) and the available data of this flux tower site is from 1 January 2004 to 31 December 2010.

The following pre-processed daily variables were used: $(1)$ air temperature $\left(\mathrm{Ta},{ }^{\circ} \mathrm{C}\right)$; (2) vapor pressure deficit (VPD, hPa); (3) precipitation (PPT, $\mathrm{mm} \mathrm{day}^{-1}$ ); (4) soil water content (SWC, \% vol); (5) latent heat $\left(\mathrm{LE}, \mathrm{W} \mathrm{m}^{-2}\right)$ (6) sensible heat $\left(\mathrm{H}, \mathrm{W} \mathrm{m}^{-2}\right)$; and (7) gross primary productivity (GPP_T, $\mathrm{g} \mathrm{C} \mathrm{m}^{-2}$ day $\left.^{-1}\right)$.

\subsection{Statistical Methods}

Buys-Ballot tables [9] were used to study the intra-annual variability of meteorological data, energy fluxes and GPP. Secondly, Granger causality tests [10] were used to study dynamic relationships between variables. The statistical analysis was computed through Statgraphics 18 (StatPoint Technologies Inc., Warrenton, VA, USA), Eviews 10 University edition (IHS Global Inc., Irvine, CA, USA) and SAS software (SAS 9.4 Software, SAS Institute Inc., Cary, NC, USA).

\section{Results and Discussion}

In Germany, $\mathrm{H}$ and LE increases with temperature during spring. However, while LE increases together with GPP during the growing period due to the link between growth and ETP, $\mathrm{H}$ reaches its maximum during May when the crop begins to cover the ground and the energy inverted to change temperature stabilizes. The majority of Net radiation is converted into latent heat. After harvest, sensible heat reaches its maximum in August because the crop has been disappeared and does not influence on temperature. Latent heat decreases because there is no crop and no ETP. Gao et al. [11] also showed that during growing season latent heat was the main consumer of net radiation, while sensible heat was dominant during the non-growing season in a rainfed maize crop.

In Spain, sensible heat reaches its maximum in mid-April when there is no crop and between flooded periods. Latent heat has two cycles that coincides with flooded periods. The first one is related to evaporation and the second one to ETP. Other studies highlighted that latent heat is the main component of available energy in rice crops [12].

Figure 1 shows the Granger causality tests between H and LE and GPP in both directions (i.e., variable cause GPP and GPP cause variable). In Germany, sensible heat causes GPP at very short term (first three lags). Then, both directions show similar F-test values. In Spain, from lag 2 to 10 GPP causes $\mathrm{H}$ more than in the other direction. In both sites, GPP causes Latent heat more than backwards. However, in Germany F-tests are much higher than in Spain especially in the sense GPP causes LE. 
a)

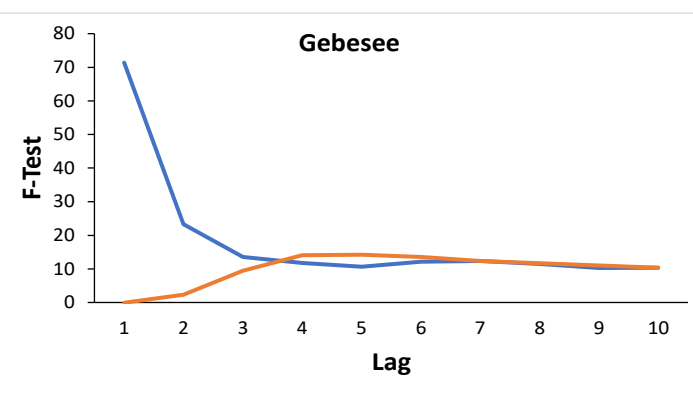

b)

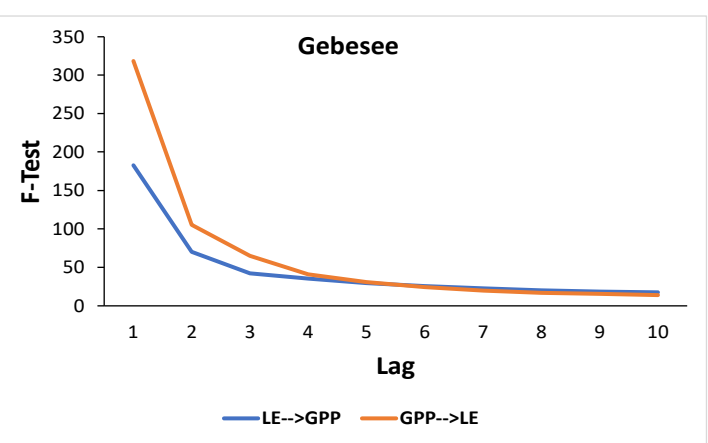

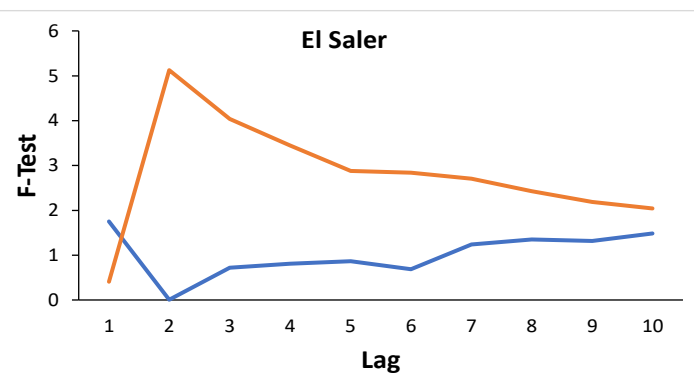

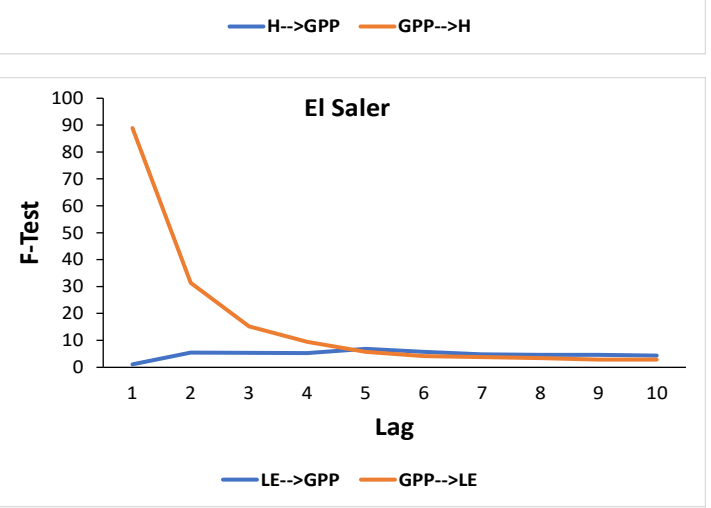

Figure 1. Granger causality test between gross primary production GPP_T $\left(\mathrm{g} \mathrm{C} \mathrm{m}^{-2}\right.$ day $\left.^{-1}\right)$ and (a) sensible heat $\mathrm{H}\left(\mathrm{W} \mathrm{m}^{-2}\right)$ and (b) latent heat LE $\left(\mathrm{W} \mathrm{m}^{-2}\right)$ in the two croplands (Left: Germany (DE), Right: Spain (ES)).

These feedback processes that vegetation exerts on the energy partitioning have been assessed by several authors [13,14].

\section{Conclusions}

Differences in GPP values and dynamics between sites are due to different crops and their interaction with the meteorological variables in each climate. GPP depends mainly on temperature especially in irrigated crops. In terms of energy fluxes, latent heat is more coupled to GPP in rainfed crops and the sensible heat depends especially on ground cover in both crops. There is a clear feedback between GPP, meteorological variables and energy fluxes in both type of crops that we have quantify by Granger causality tests. In this sense, GPP causes temperature and latent heat, especially in rainfed crops.

Author Contributions: Conceptualization, V.C., J.L., V.S.-G., A.P.-O.; methodology, V.C., J.L., V.S.-G., L.R., A.P.-O.; software, V.C., J.L.; formal analysis, V.C., J.L., A.P.-O.; investigation, V.C., J.L., V.S.-G., L.R., C.S., A.P.-O.; resources, J.L., A.P.-O.; writing-original draft preparation, V.C., J.L., V.S.-G., L.R., C.S., A.P.-O.; writing-review and editing, V.C., J.L., V.S.-G., L.R., C.S., A.P.-O.; supervision, A.P.-O.; funding acquisition, A.P.-O. All authors have read and agreed to the published version of the manuscript.

Funding: This research was funded by the Universidad Politécnica de Madrid within the project RP2013210028: “Generación de un observatorio de dinámica de la vegetación a distintas escalas a partir de series de tiempo de imágenes de teledetección".

Acknowledgments: We would like to thank the FLUXNET2015 data set and the European Fluxes Database Cluster for the assignment and permission to download the data of Gebesee and El SalerSueca, respectively.

Conflicts of Interest: The authors declare no conflict of interest. The funders had no role in the design of the study; in the collection, analyses, or interpretation of data; in the writing of the manuscript, or in the decision to publish the results. 


\section{References}

1. Malmström, C.M.; Thompson, M.V.; Juday, G.P.; Los, S.O.; Randerson, J.T.; Field, C.B. Interannual variation in global-scale net primary production: Testing model estimates. Glob. Biogeochem. Cycles 1997, 11, 367-392. [CrossRef]

2. Arora, V. Modeling vegetation as a dynamic component in soil-vegetation-atmosphere transfer schemes and hydrological models. Rev. Geophys. 2002, 40, 1006. [CrossRef]

3. Jung, M.; Reichstein, M.; Margolis, H.A.; Cescatti, A.; Richardson, A.D.; Arain, M.A.; Arneth, A.; Bernhofer, C.; Bonal, D.; Chen, J.; et al. Global patterns of land-atmosphere fluxes of carbon dioxide, latent heat, and sensible heat derived from eddy covariance, satellite, and meteorological observations. J. Geophys. Res. 2011, 116, G00J07. [CrossRef]

4. Aubinet, M.; Vesala, T.; Papale, D. (Eds.) Eddy Covariance: A Practical Guide to Measurement and Data Analysis; Springer: Dordrecht, The Netherlands, 2012; ISBN 978-94-007-2350-4.

5. Huesca, M.; Litago, J.; Palacios-Orueta, A.; Montes, F.; Sebastián-López, A.; Escribano, P. Assessment of forest fire seasonality using MODIS fire potential: A time series approach. Agric. For. Meteorol. 2009, 149, 1946-1955. [CrossRef]

6. Pastorello, G.; Trotta, C.; Canfora, E.; Chu, H.; Christianson, D.; Cheah, Y.-W.; Poindexter, C.; Chen, J.; Elbashandy, A.; Humphrey, M.; et al. The FLUXNET2015 dataset and the ONEFlux processing pipeline for eddy covariance data. Sci. Data 2020, 7, 225. [CrossRef] [PubMed]

7. Anthoni, P.M.; Knohl, A.; Rebmann, C.; Freibauer, A.; Mund, M.; Ziegler, W.; Kolle, O.; Schulze, E.-D. Forest and agricultural land-use-dependent $\mathrm{CO}_{2}$ exchange in Thuringia, Germany. Glob. Chang. Biol. 2004, 10, 2005-2019. [CrossRef]

8. SUECA. Available online: http:/ / ceamflux.com:9090/sueca/index.html (accessed on 20 May 2021).

9. Buys-Ballot, C.H.D. Les Changements périodiques de température, dépendants de la nature du soleil et de la lune, mis en rapport avec le pronostic du temps, déduits d'observations néerlandaises de 1729 à 1846; Kemink: Utrecht, The Netherlands, 1847.

10. Granger, C.W.J. Investigating Causal Relations by Econometric Models and Cross-spectral Methods. Econometrica 1969, 37, 424-438. [CrossRef]

11. Gao, X.; Mei, X.; Gu, F.; Hao, W.; Gong, D.; Li, H. Evapotranspiration partitioning and energy budget in a rainfed spring maize field on the Loess Plateau, China. CATENA 2018, 166, 249-259. [CrossRef]

12. Liu, B.; Cui, Y.; Luo, Y.; Shi, Y.; Liu, M.; Liu, F. Energy partitioning and evapotranspiration over a rotated paddy field in Southern China. Agric. For. Meteorol. 2019, 276-277, 107626. [CrossRef]

13. Wang, P.; Li, X.; Tong, Y.; Huang, Y.; Yang, X.; Wu, X. Vegetation dynamics dominate the energy flux partitioning across typical ecosystem in the Heihe River Basin: Observation with numerical modeling. J. Geogr. Sci. 2019, 29, 1565-1577. [CrossRef]

14. Forzieri, G.; Miralles, D.G.; Ciais, P.; Alkama, R.; Ryu, Y.; Duveiller, G.; Zhang, K.; Robertson, E.; Kautz, M.; Martens, B.; et al. Increased control of vegetation on global terrestrial energy fluxes. Nat. Clim. Chang. 2020, 10, 356-362. [CrossRef] 